\title{
Pengaruh Kombinasi Pupuk Kandang Sapi dan Abu Sabut Kelapa sebagai Pupuk Utama dalam Budidaya Tanaman Brokoli (Brassica oleracia L.)
}

DOI 10.18196/pt.2016.061.95-100

\author{
Eko Binti Lestari \\ Balai Pengkajian Teknologi Pertanian Papua, Jl. Yahim No.49 Sentani Jayapura Kotak Pos 256 Sentani \\ Jayapura Papua 99352 Indonesia, Telp. (0967) 592179, Fax (0967) 591235, \\ e-mail: binti.ryy@gmail.com
}

\begin{abstract}
ABSTRAK
Penelitian ini bertujuan untuk menguji efektifitas penggunaan abu sabut kelapa sebagai penambah unsur hara pada tanaman brokoli serta untuk mendapatkan kombinasi pupuk kandang dan abu sabut kelapa yang paling efektif dan efisien untuk budidaya tanaman brokoli secara organik. Penelitian dirancang dengan metode percobaan faktor tunggal yang disusun dalam rancangan acak kelompok lengkap (RAKL) yang terdiri dari 9 perlakuan, yaitu (1) Pupuk kandang sapi 0,75 kg + Abu sabut kelapa 24,3 g per tanaman, (2) Pupuk kandang sapi 0,75 kg + Abu sabut kelapa 12,15 g per tanaman, (3) Pupuk kandang sapi 0,75 kg, (4) Pupuk kandang sapi 1 kg + Abu sabut kelapa 24,3 g per tanaman,(5) Pupuk kandang sapi 1 kg + Abu sabut kelapa 12,15 g per tanaman, (6) Pupuk kandang sapi 1 kg, (7) Pupuk kandang sapi 1,25 kg + Abu sabut kelapa 24,3 g per tanaman, (8) Pupuk kandang sapi 1,25 kg + Abu sabut kelapa 12,15 g per tanaman, (9) Pupuk kandang sapi 1,25 kg. Hasil penelitian menunjukkan bahwa antar perlakuan berpengaruh tidak berbeda nyata terhadap jumlah daun, waktu pembungaan, brangkasan segar, diameter bunga dan bobot bunga segar, namun, memberikan pengaruh nyata terhadap bobot bunga setelah simpan dengan penurunan bobot terkecil ditunjukan pada perlakuan (7) Pupuk kandang sapi 1,25 kg + Abu sabut kelapa 24,3 g per tanaman. Berdasarkan hasil penelitian,dapat disimpulkan bahwa perlakuan yang paling efisien digunakan untuk budidaya brokoli secara organik adalah penggunaan pupuk kandang sapi dengan takaran 0,75 kg pertanaman.

Kata Kunci : Brokoli, Pupuk Kandang Sapi, Abu Sabut Kelapa
\end{abstract}

\begin{abstract}
This research aims to study the effectiveness of coconut fibre ash as an additive nutrient for growth and yield of Broccoli (Brassica oleracia L.), and to determine the best combination between manure and coconut fibre ash in organic farming of Broccoli. This research conducted using single factor experiment that arranged in Randomized Completely Block Design (RCBD). The treatments are (1) Manure 0,75 kg + Coconut fire ash 24,3 g (2) Manure 0,75 kg + Coconut fibre ash12,15 g, (3) Manure 0,75 kg + without Coconut fibre ash, (4) Manure $1 \mathrm{~kg}+$ Coconut fibre ash 24,3 g, (5) Manure $1 \mathrm{~kg}+$ Coconut fibre ash 12,15 g, (6) Manure $1 \mathrm{~kg}+$ without coconut fibre ash, (7) Manure 1,25 kg + Coconut fibre ash 24,3 g, (8) Manure 1,25 kg + Coconut fibre ash 12,15 g, (9) Manure 1,25 kg + without coconut fibre ash. The result showed that the combination between manure and coconut fibre ash have not significantly different in number of leaves, flowering time, fresh weight, flower size, fresh weight of flower. However, the combination between manure 1,25 kg and coconut fibre ash 24,3g is considered to be the most efficient in organic farming of Broccoli. Keywords: Broccoli, Cow manure, Coconut fiber ash
\end{abstract}

\section{PENDAHULUAN}

Brokoli (Brassica oleracea) merupakan tanaman ani untuk membudidayakan tanaman brokoli sayuran yang termasuk dalam suku kubis-kubisan atau Brassicaceae. Brokoli berasal dari daerah Laut Tengah dan sudah sejak masa Yunani Kuno dibudidayakan, sayuran ini masuk ke Indonesia sekitar 1970. Tanaman brokoli saat ini sangat popular di masyarakat karena berbagai manfaat yang dimiliki.

Kecenderungan penggunaan produk organik yang saat ini semakin meluas mendorong petsecara organik. Dalam budidaya brokoli petani menggunakan pupuk organik sebagai penyedia unsur hara yang dibutuhkan tanaman. Berdasarkan hasil survei yang telah dilakukan di Dusun Selongisor, petani menggunakan pupuk dasar berupa pupuk kandang sapi sebanyak 50 ton per hektar atau lebih banyak bila dibandingkan dengan penggunaan pupuk kandang dalam budidaya secara konvensional yaitu 12,5 - 17,5 ton per 
hektar (Rukmana, 1994). Harga pupuk kandang yang cukup tinggi menyebabkan peningkatan biaya untuk modal awal sehingga apabila harga brokoli turun maka petani dapat mengalami kerugian. Selain itu ketersediaan pupuk kandang yang mulai terbatas juga dapat menyebabkan petani kesulitan untuk memperoleh bahan tersebut. Untuk mengurangi penggunaan pupuk kandang yang diperlukan oleh petani dalam budidaya brokoli maka perlu adanya penambahan bahan alami lainya yang dapat dijadikan sebagai penambah unsur hara pengganti pupuk kandang seperti penambahan sabut kelapa.

Sabut kelapa merupakan limbah organik yang berpotensi sebagai penambah unsur hara dalam tanah. $\mathrm{K}_{2} \mathrm{O}$ yang terkandung dalam abu sabut kelapa adalah sebesar 10,25 \%. Pemberian abu sabut kelapa sebanyak 643,940 kg per hektar pada tanaman Centrosema puberscens mampu meningkatkan $\mathrm{K}$ tersedia dalam tanah sebesar 740,07 mg, sehingga dapat meningkatkan hasil tanaman (Sunarti, 1996 dalam Hermawati, 2007). Kalium merupakan salah satu unsur hara esensial yang dibutuhkan tanaman yaitu sebagai aktivator dari berbagai enzim esensial dalam reaksi-reaksi fotosintesis dan respirasi, serta untuk enzim yang terlibat dalam sintesis protein dan pati (Lakitan, 1995) selain itu kalium juga sering disebut petani sebagai unsur hara mutu, karena berpengaruh pada ukuran, rasa, bentuk, warna dan daya simpan (Rahayu, 2012). Penelitian ini bertujuan untuk menguji efektifitas penggunaan abu sabut kelapa sebagai penambah unsur hara untuk pertumbuhan dan hasil tanaman brokoli serta untuk mendapatkan kombinasi pupuk kandang dan abu sabut kelapa yang paling efektif dan efisien digunakan dalam budidaya brokoli secara organik.

\section{BAHAN DAN METODE}

Bahan yang digunakan dalam penelitian ini adalah benih brokoli varietas sakata, pupuk kandang, limbah sabut kelapa, pupuk organik cair, pestisida organik, dan urin sapi. Penelitian dilaksanakan menggunakan metode percobaan faktor tunggal yang disusun dalam rancangan acak kelompok lengkap (RAKL). Terdiri dari 9 perlakuan sebagai berikut: (1) PA1 = Pupuk kandang 0,75 kg + Abu sabut kelapa 24,3 g; (2) PA2 = Pupuk kandang 0,75 kg + Abu sabut kelapa 12,15 g; (3) PA3 = Pupuk kandang 0,75 kg; (4) PA4 = Pupuk kandang $1 \mathrm{~kg}+$ Abu sabut kelapa 24,3 g; (5) PA5 = Pupuk kandang 1 kg + Abu sabut kelapa 12,15 g; (6) PA6 = Pupuk kandang 1 kg; (7) PA7 = Pupuk kandang 1,25 $\mathrm{kg}+$ Abu sabut kelapa 24,3 g; (8) PA8 = Pupuk kandang 1,25 kg + Abu sabut kelapa 12,15 g; (9) PA9 = Pupuk kandang 1,25 kg. Masing-masing perlakuan memiliki 3 ulangan. Parameter yang diamati dalam penelitian ini meliputi jumlah daun, waktu pembungaan, brangkasan segar, diameter bunga, bobot segar bunga, dan bobot bunga setelah disimpan.

\section{HASIL DAN PEMBAHASAN}

Pertumbuhan Tanaman

Variabel pertumbuhan tanaman yang diamati pada penelitian ini yaitu jumlah daun dan waktu pembungaan. Pengamatan jumlah daun dilakukan untuk mengetahui seberapa besar potensi yang dimiliki tanaman dalam proses fotosintesis. Pengamatan waktu pembungaan dilakukan pada saat tanaman sudah mulai berbunga $80 \%$ dalam petak percobaan.

Hasil sidik ragam menunjukkan semua perlakuan memberikan pengaruh tidak berbeda nyata terhadap jumlah daun dan waktu pembungaan. Jumlah daun yang hampir sama menunjukkan bahwa potensi tanaman dalam 
melakukan proses fotosintesis juga sama. Hal ini diduga disebabkan karena semua tanaman dapat menyerap unsur hara esensial dengan kemampuan yang hampir sama. Kondisi lahan yang sudah terbiasa digunakan dalam budidaya secara organik dengan menggunakan pupuk kandang sebagai pupuk utama menyebabkan tanah tersebut memiliki kandungan unsur hara tersedia cukup banyak sehingga perbedaan perlakuan hasilnya tidak berpengaruh nyata pertumbuhan jumlah daun. Sutanto (2002) menyebutkan bahwa penelitian jangka panjang yang dilakukan oleh Departemen Kimia Tanah IRRI menunjukan bahwa pembenaman kembali jerami di lahan secara nyata meningkatkan hara didalam tanah. Hal yang sama juga dilaporkan oleh Nakada (1981) dalam Sutanto (2002) bahwa terjadi kenaikan N, P, K dan Si dalam tanah disebabkan karena pemberian kompos dalam jangka panjang.

Tabel 1. Rerata Jumlah Daun (9 MST) dan Waktu Pembungaan Brokoli setelah Diberikan Pupuk Kandang dan Abu Sabut Kelapa dengan Berbagai

\begin{tabular}{lcc}
\hline \multicolumn{1}{c}{ Perlakuan } & $\begin{array}{c}\text { Jumlah daun } \\
\text { (helai) }\end{array}$ & $\begin{array}{c}\text { Waktu pembungaan } \\
\text { (HST) }\end{array}$ \\
\hline Pupuk kandang $0,75 \mathrm{~kg}+$ ASK 24,3 g & 17 & 64 \\
Pupuk kandang $0,75 \mathrm{~kg}+$ ASK 12,15 g & 18 & 70 \\
Pupuk kandang $0,75 \mathrm{~kg}+$ Tanpa ASK & 17 & 68 \\
Pupuk kandang1 kg + ASK 24,3 g & 19 & 68 \\
Pupuk kandang 1 kg + ASK 12,15 g & 18 & 68 \\
Pupuk kandang 1 kg + Tanpa ASK & 18 & 67 \\
Pupuk kandang 1,25 kg + ASK 24,3 g & 19 & 67 \\
Pupuk kandang 1,25 kg + ASK 12,15 g & 18 & 66 \\
Pupuk kandang 1,25 kg + Tanpa ASK & 17 & 68 \\
\hline Sidik Ragam & $\mathrm{ns}$ & $\mathrm{ns}$ \\
\hline
\end{tabular}

Hasil analisis ragam menunjukkan pengaruh yang tidak berbeda nyata antar perlakuan terhadap waktu pembungaan. Perbedaan takaran pupuk kandang sapi dan abu sabut kelapa memberikan pengaruh yang sama terhadap percepa- tan pembungaan brokoli. Tidak adanya pengaruh yang berbeda nyata menunjukan bahwa tanaman memiliki kemampuan yang hampir sama dalam menyerap unsur hara. Penyerapan unsur hara oleh tanaman sangat dipengaruhi dengan ketersediaan unsur hara dalam tanah. Penggunaan pupuk kandang sapi dan abu sabut kelapa dapat meningkatkan kandungan unsur hara dalam tanah. Sanchez (1976) menyatakan bahwa dalam proses budidaya tanaman sayuran perlu adanya kajian kebutuhan hara untuk efisiensi penggunaan pupuk melalui pendekatan ketetapan jenis, takaran, cara dan waktu aplikasi pupuk sesuai sifatnya.

\section{Hasil Tanaman}

Variabel hasil tanaman yang diamati pada penelitian ini yaitu bobot brangkasan segar dalam satuan $\mathrm{kg}$, diameter bunga dalam satuan $\mathrm{cm}$, bobot bunga segar dalam satuan kg dan bobot bunga setelah disimpan selama 5 hari dalam satuan kg. Bagian yang dikonsumsi dari tanaman brokoli adalah massa bunganya (curd) dengan mengukur diameter dari bunga maka dapat dilihat pengaruh dari pemberian pupuk kandang dan abu sabut kelapa.

Tabel 2. Rerata Brangkasan Segar dan Diameter Bunga Brokoli Setelah Diberikan Pupuk Kandang dan Abu Sabut Kelapa dengan Berbagai Dosis

\begin{tabular}{lcc}
\hline \multicolumn{1}{c}{ Perlakuan } & $\begin{array}{c}\text { Brangkasan segar } \\
(\mathrm{kg})\end{array}$ & $\begin{array}{c}\text { Diameter bunga } \\
(\mathrm{cm})\end{array}$ \\
\hline Pupuk kandang $0,75 \mathrm{~kg}+$ ASK 24,3 g & 0.83 & 13.54 \\
Pupuk kandang $0,75 \mathrm{~kg}+$ ASK 12,15 g & 0.74 & 12.88 \\
Pupuk kandang $0,75 \mathrm{~kg}+$ Tanpa ASK & 0.81 & 13.85 \\
Pupuk kandang1 kg + ASK 24,3 g & 0.73 & 12.38 \\
Pupuk kandang 1 kg + ASK 12,15 g & 0.74 & 13.42 \\
Pupuk kandang 1 kg + Tanpa ASK & 0.76 & 12.71 \\
Pupuk kandang 1,25 kg + ASK 24,3 g & 0.81 & 14.10 \\
Pupuk kandang 1,25 kg + ASK 12,15 g & 0.77 & 12.63 \\
Pupuk kandang 1,25 kg + Tanpa ASK & 0.84 & 13.83 \\
\hline Sidik Ragam & ns & ns \\
\hline Keterangan : HST = Hari Setelah Tanaman, ASK = Abu Sabut Kelapa, ns = Not Significant
\end{tabular}

Keterangan : HST = Hari Setelah Tanaman, ASK = Abu Sabut Kelapa, ns = Not Significant 
Brangkasan segar brokoli antar perlakuan yang dipengaruhi dosis pupuk kandang dan Abu Sabut kelapa yang berbeda menunjukkan tidak terdapat beda nyata. Perbedaan perlakuan pupuk pada tanaman brokoli tidak mempengaruhi proses fotosintesis yang berlangsung pada semua tanaman. Apabila proses fotosintesis berjalan dengan baik maka semakin besar fotosintat yang dihasilkan. Fotosintat tersebut digunakan untuk pertumbuhan dan perkembangan tanaman, antara laian pertambahan jumlah daun, tinggi tanaman, panjang akar dan lain sebagainya. Hal ini diduga karena kondisi tanah yang digunakan untuk penelitian ini sudah dalam keadaan yang subur, sehingga tanaman brokoli pada semua perlakuan dapat melakukan penyerapan unsur hara dan proses pertumbuhan yang hampir sama. Seperti disebutkan oleh Meritus (1990) dalam Marliah, dkk (2013) bahwa apabila ketersediaan unsur hara yang dibutuhkan tanaman berada dalam keadaan cukup, maka hasil metabolismenya akan membentuk protein, enzim, hormon dan karbohidarat, sehingga perpanjangan dan pembelahan sel akan berlangsung maksimal.

Perbedaan kombinasi dan takaran pupuk dasar ternyata tidak terlalu mempengaruhi diameter bunga. Hal ini menunjukan bahwa unsur hara dan air yang ada dalam tanah dapat diserap tanaman dengan baik. Seperti disebutkan oleh Wasonowati (2009) pada waktu mengalami kekurangan air dan unsur hara maka laju pertumbuhan tanaman akan menurun, laju pembesaran sel lebih lambat sehinga ukuran sel lebih kecil dan pembentukan bunga terhambat akibatnya akan berpengaruh terhadap hasil produksi.

Perlakuan pupuk kandang 1,25 kg yang ditambahkan abu sabut kelapa 24,3 g memiliki diameter bunga yang paling tinggi bila dibandingkan dengan perlakuan yang lain. Hal ini karena kombinasi perlakuan pupuk kandang dan abu sabut kelapa dengan takaran maksimal menambahkan unsur hara tersedia dalam tanah.

Unsur kalium yang terkandung dalam abu sabut kelapa berperan untuk mengaktifkan enzim-enzim esensial dalam proses fotosintesis serta dalam penyusunan protein dan pati. Hermawati (2007) menjelaskan bahwa dalam proses fotosintesis, kalium berperan mengatur potensi osmotic sel. Perubahan osmotic sel mempengaruhi proses menutup dan membukanya stomata. Apabila kalium alam sel meningkat maka potensi osmotic sel menjadi negatif akibatnya stomata membuka. Proses pembukaan stomata memudahkan $\mathrm{CO}_{2}$ masuk kedalam daun dan kemudian dimanfaatkan oleh daun dalam proses fotosintesis. Dengan laju fotosintesis yang optimal maka pertumbuhan tanaman brokoli lebih baik dan menambah diameter bunga yang dimiliki oleh tanaman dengan perlakuan pupuk kandang 1,25 kg yang ditambahkan abu sabut kelapa 24,3 g.

Tabel 3. Rerata Bobot Segar Bunga saat Segar maupun setelah Disimpan selama 5 Hari setelah Diberikan Pupuk Kandang dan Abu Sabut Kelapa dengan Berbagai Dosis

\begin{tabular}{lcc}
\hline \multicolumn{1}{c}{ Perlakuan } & $\begin{array}{c}\text { Bobot Bunga Segar } \\
(\mathrm{kg})\end{array}$ & $\begin{array}{c}\text { Bobot Bunga setelah } \\
\text { disimpan }(\mathrm{kg})\end{array}$ \\
\hline Pupuk kandang $0,75 \mathrm{~kg}+$ ASK 24,3 g & 0.23 & $0.18 \mathrm{ab}$ \\
Pupuk kandang $0,75 \mathrm{~kg}+$ ASK 12,15 g & 0.19 & $0.15 \mathrm{ab}$ \\
Pupuk kandang 0,75 kg + Tanpa ASK & 0.22 & $0.18 \mathrm{ab}$ \\
Pupuk kandang1 kg + ASK 24,3 g & 0.20 & $0.14 \mathrm{~b}$ \\
Pupuk kandang 1 kg + ASK 12,15 g & 0.22 & $0.17 \mathrm{ab}$ \\
Pupuk kandang 1 kg + Tanpa ASK & 0.20 & $0.17 \mathrm{ab}$ \\
Pupuk kandang 1,25 kg + ASK 24,3 g & 0.24 & $0.21 \mathrm{a}$ \\
Pupuk kandang 1,25 kg + ASK 12,15 g & 0.20 & $0.17 \mathrm{ab}$ \\
Pupuk kandang 1,25 kg + Tanpa ASK & 0.24 & $0.19 \mathrm{ab}$ \\
\hline Sidik Ragam & $\mathrm{ns}$ & \\
\hline
\end{tabular}

Keterangan : HST = Hari Setelah Tanaman, ASK = Abu Sabut Kelapa, ns = Not Significant. Angka pada kolom yang diikuti oleh huruf yang sama menunjukan tidak ada beda nyata berdasar Uji Jarak Berganda Duncan $5 \%$.

Pengukuran bobot segar digunakan untuk merepresentasikan seberapa besar penyerapan unsur hara oleh tanaman yang ditranslokasikan 
kepada pembentukan bunga brokoli. Hal ini erat kaitannya dengan kualitas brokoli yang diukur dari bobot segar bunga, karena bunga brokoli merupakan bagian tanaman yang dikonsumsi oleh masyarakat. Tidak adanya pengaruh nyata perlakuan terhadap bobot segar bunga menunjukan bahwa perbedaan kombinasi dan takaran perlakuan yang diberikan tidak mengganggu pertumbuhan tanaman sehingga dapat menghasilkan bobot segar bunga yang hampir sama. Hasil tanaman sangat dipengaruhi oleh serapan unsur hara yang dilakukan oleh tanaman selama fase vegetatif maupun generatif. Ketersediaan unsur hara bersifat kritis karena unsur hara mutlak harus tersedia bagi tanaman dengan unsur yang sangat spesifik dan tidak tergantikan oleh unsur lainnya serta dalam jumlah yang berbeda. Kekurangan unsur hara akan menghambat pertumbuhan dan perkembangan tanaman, karena unsur hara merupakan makanan bagi tanaman untuk menghasilkan energi yang dapat membantu dalam proses metabolisme tanaman. Apabila salah satu unsur hara yang dibutuhkan oleh tanaman tidak tersedia maka proses metabolisme tanaman akan berhenti. Hal tersebut tentu akan sangat berpengaruh terhadap pertumbuhan dan hasil tanaman yang dibudidayakan. Dengan kondisi tanah yang memang sudah subur maka dapat merangsang pertumbuhan vegetatif tanaman dengan sangat baik. Ketika pertumbuhan tanaman pada fase vegetatif sudah baik maka akan berpengaruh pada pembentukan bunga. Bobot bunga yang berkisar antara 0,19 kg - 0,24 kg merupakan bobot yang biasa dimiliki oleh bunga brokoli, hal ini sama halnya dengan bobot segar bunga pada hasil penelitian Wasonowati (2009) bahwa bobot bunga segar brokoli berkisar antara $0,20 \mathrm{~kg}-0,28 \mathrm{~kg}$.
Pada pengamatan bobot bunga setelah disimpan menunjukan bahwa perlakuan memberikan pengaruh berbeda nyata. Seperti dapat dilihat bahwa perlakuan pupuk kandang 1,25 kg yang ditambahkan dengan abu sabut kelapa 24,3 g memiliki penurunan bobot paling sedikit, hal ini berarti kandungan air dalam bunga masih tinggi. Kondisi tersebut disebabkan karena penambahan pupuk kandang dan abu sabut kelapa dengan takaran yang maksimal mampu mempertahankan bobot bunga setelah disimpan selama 5 hari. Penambahan abu sabut kelapa yang digunakan sebagai bahan peambah unsur hara K untuk tanaman ternyata memberikan pengaruh pada daya simpan brokoli. Seperti disebutkan oleh Rahayu (2012) bahwa kalium sering disebut petani sebagai unsur hara mutu, karena berpengaruh pada ukuran, rasa, bentuk, warna dan daya simpan. Selain itu disampaikan oleh Affandie (2002) fungsi utama kalium adalah mengaktifkan enzim-enzim dan menjaga air dalam sel.

\section{SIMPULAN}

Penggunaan kombinasi pupuk kandang sapi dan abu sabut kelapa dengan takaran yang berbeda tidak memberikan pengaruh nyata terhadap pertumbuhan tanaman brokoli, terlihat dari hasil analisis sidik ragam yang menyatakan tidak adanya pengaruh beda nyata oleh perlakuan terhadap jumlah daun, waktu pembungaan, brangkasan segar, bobot bunga segar.

Seluruh perlakuan memberikan efek positif terhadap pertumbuhan tanaman sehingga perlakuan yang paling efisien digunakan dalam budidaya brokoli adalah pupuk kandang sapi dengan takaran $0,75 \mathrm{~kg}$ per tanaman atau setara dengan 30 ton per hektar. 


\section{DAFTAR PUSTAKA}

Afandie, R., Nasih, P,W. 2002. Ilmu Kesuburan Tanah. Penerbit Kanisius, Yogyakarta

Hermawati T. 2007. Respon Tanaman Semangka (Citrullus vulgarisschard.) terhadap Pemberian Berbagai Dosis Abu Sabut Kelapa. Fakultas Pertanian. Universitas Jambi. Jambi

Lakitan B.1995. Dasar-dasar Fisiologis Tumbuhan. PT. Rajagrafindo Persada. Jakarta.

Marliah, A., Nurhayati, Risma Riana. 2013. Pengaruh Varietas Dan Konsentrasi Pupuk Majemuk Terhadap Pertumbuhan Dan Hasil Tanaman Kubis Bunga (Brassica Oleracea L.). Prodi Agroteknologi Fakultas Pertanian Universitas Syiah Kuala, Banda Aceh

Rahayu indah. 2012. Manfaat Unsur K Pada Tanaman. http:// indahrahayu7.blogspot.com/2012/09/manfaat-unsur-k-padatanaman.html. Diakses tanggal 23 Januari 2014.

Rukmana R. 1993. Budidaya Kubis Bunga dan Brokoli. Kanisius. Yogyakarta.

Sanchez, P.A. 1976. Sifat dan Pengelolaan Tanah Tropika. Terjaman J.T. Jayadinata. 1992. ITB. Bandung

Sutanto R. 2002. Penerapan Pertanian Organik. Kanisius, Yogyakarta.

Wasonowati catur. 2009. Kajian Saat Pemberian Pupuk Dasar Nitrogen Dan Umur Bibit Pada Tanaman Brokoli (Brassica oleracia L.). Fakultas Pertanian. Universitas Trunojoyo Madura. Agrovigor (2): 24-32. 